\title{
THE CONTRIBUTION OF THE SERAMBI INDONESIA AND WASPADA NEWSPAPERS IN IMPLEMENTATION OF THE ISLAMIC LAW IN ACEH
}

\author{
Darmadi \\ Fakultas Ushuluddin, Adab dan Dakwah IAIN Lhokseumawe \\ Jl. Medan Banda Aceh, Km. 275 No. 1 Desa Alue Awe, Lhokseumawe, 24351 \\ e-mail: darmadi@iainlhokseumawe.ac.id, darmadi_tot2@yahoo.com
}

\begin{abstract}
This study investigates the role of media in implementing Islamic law and overcoming aqîdah trivialization in Aceh, which focuses on the contribution of Serambi Indonesia and Waspada newspapers. The results show that, the two newspapers play important roles in socializing Qanun as regulations on Islamic law; reporting Qanun socialization from Islamic law institution; publishing news on the implementation and supervision of the Islamic law, providing some comments from the leaders regarding the implementation of the Islamic law to prevent aqîdah trivialization. Constraints faced by the Media in reporting the issues of sharia implementation and shallowing faith of the ummah include terror and intimidation; a must to conceal the identity of the under-age; and the difficulty of confirming and clarifying with informants/perpetrators.
\end{abstract}

\begin{abstract}
Abstrak: Artikel ini berupaya mengkaji peran media massa terhadap implementasi Syariat Islam di Aceh. Kajian ini difokuskan pada kontribusi surat kabar Serambi Indonesia dan Waspada dalam mengatasi pendangkalan akidah di Aceh. Hasil penelitian menyatakan bahwa, peran media dalam rangka pelaksanaan Syariat Islam dan upaya pendangkalan akidah antara lain mensosialisasikan aturan-aturan Qanun tentang Syariat Islam; memberitakan sosialisasi Qanun oleh Dinas Syariat Islam; memuat berita pelaksanaan dan pengawasan Syariat Islam, memuat komentar tokoh berkenaan dengan pelaksanaan Syariat Islam dan upaya pendangkalan akidah umat. Kendala-kendala yang dihadapi oleh media dalam pemberitaan pelaksanaan Syariat Islam dan upaya pendangkalan akidah umat antara lain teror atau intimidasi untuk tidak memberitakan berita; harus menyembunyikan identitas pelaku jika masih di bawah umur; dan sulitnya melakukan konfirmasi dan klarifikasi dengan narasumber baik pelaku pelanggaran Syariat Islam maupun yang berkaitan dengan aliran sesat.
\end{abstract}

Keywords: mass media, Islamic sharia, aqidah, deviant sects 


\section{Introduction}

Aceh is one of the regions that has specialties in the implementation of Islamic Sharia comprehensively. Since its first adoption in 2004, Islamic Sharia in Aceh in its implementation has colored the social, cultural, economic and political realities of society. In the process, the implementation of Islamic Sharia in Aceh needs to be socialized to the public through the mass media, so that its implementation can run in accordance with the substantial objectives of implementing Islamic Sharia in Aceh. Mass media can be used as a tool to increase public environmental awareness and is a major factor in shaping individual attitudes. ${ }^{1}$ Mass media is a source of information and education for the community and is the spirit of the struggle for the democratization of a nation because of its presence as a source of community empowerment. ${ }^{2}$ Media effects can affect not only the relationship between the media and the audience, but also at a higher, even global level. ${ }^{3}$ News about Islamic Sharia needs to be well framed to provide interpretation to the public about the importance of implementing Islamic Sharia. Framing of important news is done, aiming to influence individuals in assessing and interpreting the issues contained in a news. ${ }^{4}$ Moreover, the formalization of Islamic Sharia in Aceh has drawn pros and cons among moderate and conservative societies. ${ }^{5}$

So in this case, there are various ways to convey the concept of implementing Islamic Sharia in Aceh such as socialization through various scientific study forums, seminars, workshops, banners, posters and even mass media. The mass media is one of the solutions for the Aceh Sharia Islamic Service to succeed in implementing Islamic Sharia in Aceh in a comprehensive and holistic manner. Because the mass media is actually present in the midst of society to provide enlightenment related to various developing issues. Thus, framing news through the media agenda provides certain influences and interpretations to create public opinion. This public opinion can control the attitudes and thoughts of the public.

${ }^{1}$ Troy Elias, et al., "Media Use, Cross-National Samples, and the Theory of Planned Behavior: Implications for Climate Change Advocacy Intentions," in International Journal of Communication, Vol. 13, 2019, p. 3694-3718.

2 Tias Satrio Adhitama, "Kartun Humor dan Misi Dakwah dalam Media Cetak," in Jurnal Komunikasi Islam, Vol. 04, No. 01, Juni 2014, p. 112.

${ }^{3}$ Sandra Veinberg, "Most Dominated Problem fo Mass Media Dialogism in National Dailies During the Trial Process of Wikileaks Grounder Julian Assange," in International Journal of Social Science Studies, Vol. 2, No. 2, 2014, p. 43.

${ }^{4}$ Muhammad Syahri Zamri dan Mohamad Saifudin Mohamad Saleh, "Analisis Pelaporan Atlet Wanita Islam Semasa Sukan SEA 2015 dan 2017 in Utusan Online dan Berita Harian Online," in Malaysian Journal of Media Studies, Vol. 21, No. 1, 2019, p. 51.

${ }^{5}$ Iman Jauhari, "Pelaksanaan dan Penegakan Syariat Islam di Aceh," in Jurnal Hukum Pro Justitia, Vol. 28, April 2010, p. 30. Discussion on how the convergence of Islamic and secular laws, see in general, Mhd. Syahnan, Modernization of Islamic Law of Contract (Jakarta: Badan Litbang \& Diklat Departemen Agama RI, 2009). 
However, it is an advantage for some interested parties if the mass media is present in the community to provide enlightenment. ${ }^{6}$

The mass media is used as a tool to convey the political interests of the Aceh government in the implementation of Islamic Sharia. The study of the mass media is always interesting to study in developing countries which tend to use the media as a tool of government political interests. ${ }^{7}$ Mass media is one of the washilah (channels) of information that can be owned and commercialized to consumers which is also called audiences, namely readers for print media (Newspapers, Magazines, Bulletin), listeners for audio media (Radio), and audiences for audio visual media (television). The term media is an information medium used to convey news and entertainment. In particular, the media does not have positive or negative goals. But from time to time the media can also become a medium for spreading positive and negative news such as propaganda to spread bad news. ${ }^{8}$ Anwar Arifin gave several descriptions of changes in the communication process. The first thing according to Arifin is information gathering, information management, information storage, information dissemination, and information retrieval (feedback). Every change in these five components in humans always affects the way society functions. ${ }^{9}$

The availability of information will be meaningless without the media that can convey the news to the public. Therefore, mass media by its nature can reach all levels of society is the main thing that can become the basis for delivering information to the general public, both locally and globally. Because the mass media is directly involved in the globalization process. Sky Marsen explains this fact for two reasons. First, they connect the world through content broadcast or accessed in most parts of the world; Audiences around the world watch the same television shows, and communicate with other international people in real time via the internet. Second, the media, in a business capacity, are often owned by multinational corporations, and are regulated according to international standards generally set by institutions that promote global uniformity and equality in mass communication. ${ }^{10}$

The presence of the mass media in socializing the implementation of Islamic Sharia

${ }^{6}$ Jaduk Gilang Pembayun, "Konglomerasi Media dan Dampaknya Pada Pilpres 2014," in INTERAKSI, Vol. 4 No. 2, Juli 2015, p. 109-116.

${ }^{7}$ Riyan Gunawan dan Ahmad, "Fungsi Media Massa dalam Perspektif Negara Demokrasi terkait Penyelenggaraan Pemilu," in Seminar Nasional Hukum Universitas Negeri Semarang Jurnal Unnes, Vol. 4, No. 3, 2018, p. 1101-1118.

${ }^{8}$ Ahmad Saufiyan, "Kempen Politik Trump: Strategi, Taktik dan Model Perangsaraf Media," in Jurnal Komunikasi, Malaysian Journal of Communication, Jilid 31, Vol. 1, 2017, p. 294-312.

${ }^{9}$ Deddy Mulyana, et al., Ilmu Komunikasi Sekarang dan Tantangan Masa Depan (Jakarta: Kencana, 2013), p. 22.

${ }^{10}$ Alevtina A. Kolosova dan Fatemeh Deilami, "Globalization, Culture, and the Role of Media," in Jurnal Journal of International Scientific Publications: Media and Mass Communication, Vol. I, 2012, p. 71. 
in Aceh has made a positive contribution. ${ }^{11}$ With the main role and function of conveying information to readers, several mass media in Aceh actively participate in disseminating various information related to the implementation of Islamic law in Aceh. With this kind of contribution, the echoes of the implementation of Islamic Sharia can quickly reach the society. In the early stages of implementing Islamic Sharia in Aceh, the mass media became one of the main channels in the socialization of qanuns as a product of Islamic Sharia.

This role did not stop here because the media also has another function, namely the function of social control of society. In carrying out this mission, the media have a more strategic role. As a forum that manages and delivers various information to the public, the mass media plays a more important role because the media go directly to society to seek information relating to the implementation of Islamic Sharia. In carrying out this social control function, the media finds and publishes news relating to the implementation of Islamic Sharia. In contrast to the functions of conveying information and socialization, the media in exploring and finding information about the application of the implementation of Islamic Law is far more dominant. The media not only receives information from related parties, but the media can obtain balanced information about various developments in the implementation of Islamic Sharia in Aceh.

This research focuses on two mass media, namely Serambi Indonesia Newspaper and Waspada. The two media have provided space in publishing news about the implementation of Islamic Law in Aceh. The comparison between the two national media was chosen with the consideration of looking at the editorial policy in selecting the news that occurred, the style of writing even though the incident data were the same between the Serambi Indonesia newspaper which was actually born and managed in Aceh and the Waspada daily newspaper published in Medan. The special attention of the two media to the news of Islamic Sharia news is a reason for the writer to choose the media. Based on the assumption that the success of a media really depends on the people who are in the media. So this media is included in the category of media with good credibility and management and reaches audiences up to remote areas of Aceh. ${ }^{12}$ This media journalist also has good competence as a professional journalist. While theoretically, from a positivistic view, newspapers are part of the mass media that have a role as surveillance, namely the supervision of their environment which includes cultural, economic, political, legal and ideological issues. The manifestation of that supervision is the result of a report. In reality, the process of presenting a story is also influenced by editorial priority plans according to the level of public interest. So that in a positivistic view, media crews and editors are passive transmitters who provide

${ }^{11}$ Darmadi, "Etika dan Profesionalisme Wartawan Serambi Indonesia dan Rakyat Aceh Dalam Peliputan Pelanggaran Syariat Islam di Provinsi Aceh," in Konfrontasi: Jurnal Kultur, Ekonomi dan Perubahan Sosial, Vol. 4, No. 2, Juli 2017, p. 20-32.

${ }^{12}$ Syahril Furqany, et al., "Manajemen Program Siaran Lokal Aceh TV dalam Upaya Penyebarluasan Syariat Islam dan Pelestarian Budaya Lokal," in Jurnal Komunikasi KAREBA, Vol. 4, No. 1, Januari-Maret 2015, p. 46-54. 
an assessment of the priority level of the importance of news for the public. In communication science terminology, this theory is called the agenda setting theory of media. Theoretically, this theory discusses three concepts of analysis, namely analysis related to the media agenda, the public agenda and the policy agenda. The scope of discussion in the concept of media analysis is the content of news, while the public agenda is related to the thoughts of the audience on news and the policy agenda discusses the relevance of policies and audiences. Specifically with regard to the area of media agenda analysis to understand the phenomenon, there are three theoretical concepts that need to be considered by researchers, namely, the concept of prominence (the relevance of issues to the audience), salience (frequency of issues), and valen (the way an issue is presented by the media, issues are presented in a way that is interesting or not. ${ }^{13}$

This can be seen from the news published by the print media, especially Serambi Indonesia and the Waspada Daily which provide information about the implementation of Islamic Sharia. The emergence of a number of reports on khalwat cases published by the two media is a form of the media's role in conveying information. Apart from seclusion, the emergence of deviant sects and rejection by the community is also one of the objects of media coverage. This proves that the media plays a strategic role in the successful implementation of Islamic Sharia in Aceh.

For example, the emergence of news about heretical sects in Peusangan, Plimbang, Banda Aceh and other places shows that the media plays a social control role in the development of religious issues in Aceh. The issue of the emergence of a cult has also become one of the central news stories in Aceh which have been reported by various media including Serambi Indonesia and the Waspada Daily. The local government also looks very responsive to this news. The form of attention of the Regional Government is to issue "fatwas" on the names of sects that are considered heretical and are not justified in Aceh. Although later problems arose after the names of the sects which were considered heretical were circulated in society. Some people who feel they are "not heretical" even clarify to the media about the problems they are accused of. In addition, there are other problems that arise which are part of the implementation of Islamic Sharia in Aceh, such as the fatwa on civet coffee, same-sex marriage and MLM practices that have appeared in the mass media which is another evidence that the media also participates in monitoring issues relating to the implementation of Sharia. Islam in Aceh. Apart from the problems mentioned above, of course there are still many other issues raised by the media, especially the Serambi Indonesia and Waspada Daily about the implementation of Islamic Sharia and the problem of efforts to suppress the aqidah of the ummah.

Based on a search of the literature, several studies were found related to mass

\footnotetext{
${ }^{13}$ Felix Tawaang, "Newspapers Media Agenda (The Capital Newspapers Content Analysis)," in Jurnal Studi Komunikasi dan Media, Vol. 19, No. 1, Januari-Juni 2015, p. 73-80. See also, EM. Griffin, A First Look at Communication Theory (New York: Mc Graw Hill, 2003).
} 
media and Islamic Sharia in Aceh. Putri Maulina conducted a study related to silencing women in the text of reporting on violations of Islamic Sharia in Aceh. The results of her research on three online media (acehkita.com, thejakartaglobe.com and bbcnews.com) show that the construction of media on women's reporting has added to the stereotype of Acehnese women as being cornered. ${ }^{14}$ Then in another study, Putri Maulina conducted a study on the daily Serambi Indonesia which stated that women were the most vulnerable to violating Islamic Sharia in Aceh in the view of the dominant discourse. ${ }^{15} \mathrm{Al}$-juanda, Hamdani M. Syam, and Muhammad Yunus conducted a comporative study of Republika and Okezone regarding Islamic Sharia reporting, stating that there are differences in the news construction of the two media. Online Republika is more balanced, meanwhile Okezone is actually cornering the implementation of Islamic Sharia which is considered contrary to the basic substance of the Indonesian nation. ${ }^{16}$ Uswatun Nisa in his research explained that the public reception of the coverage of Islamic Sharia in Aceh on Kompas.com has different interpretations of the same news according to the knowledge and experience of the readers. In contrast to the aforementioned research, this study focuses on the contribution of Serambi Indonesia and Waspada newspapers in the implementation of Islamic Sharia and the silting of aqidah. In its implementation, the author wants to see how the media performs construction in covering and writing news on the implementation of Islamic Sharia and the silting of aqidah in Aceh and how the obstacles faced by journalists of the two media in carrying out their journalistic duties.

This paper answers how Serambi Indonesia and Waspada have contributed to the implementation of Islamic Sharia and overcoming the silting of aqidah. The author believes that the Aceh government and the mass media are "symbiotic mutualism" that mutually need and benefit the implementation of Islamic Sharia in Aceh. Therefore, Serambi Indonesia and Waspada's contribution to the implementation of Islamic Sharia in Aceh needs to be studied to find the facts behind news construction and the obstacles faced by Serambi Indonesia and Waspada media in covering the implementation of Islamic Sharia in Aceh.

The method used in this research is qualitative with a descriptive approach. The main source of research data is in-depth interviews with research informants who are determined by purposive sampling. The informants interviewed were journalists from

${ }^{14}$ Putri Maulina, "Pembungkaman Terhadap Perempuan Dalam Teks Pemberitaaan Pelanggaran Syariat Islam di Aceh," in Jurnal Bidayah, Vol. VIII, No.1, Januari-Juni 2017, p. 120-133. On the discusiion of the role of women in a broader sense, see Mhd. Syahnan, et al., "Reconsidering Gender Roles in Modern Islam: A Comparison of the Images of Muslim Women Found in the Works of Sayyid Qutb and 'Â'ishah 'Abd Rahmân," in International Journal of Humanities and Social Science Invention, Vol. 6, No. 10, 2017, p. 37-42.

${ }^{15}$ Putri Maulina, "Penerapan Syariat Islam Dari Sudut Pandang Media dan Perempuan di Aceh," in Jurnal Komunikasi Global, Vol. 8, No. 2, 2019, p. 190-212.

${ }^{16}$ Al-Juanda, et al., "Penerapan Syariat Islam di Aceh in Konstruksi Pemberitaan Media Nasional (Studi Komparatif Terhadap Pemberitaan Republika Online dan Okezone)," in Jurnal Ilmiah Mahasiswa FISIP Unsyiah, Vol. 1, No. 1. Januari 2017, p. 1-14. 
Serambi Indonesia and the Waspada newspaper who worked in the city of Lhokseumawe. They were asked about their experiences in carrying out their duties as journalists, especially in reporting, especially on Islamic Sharia in Aceh.

\section{The Role of Media and the Implementation of Islamic Sharia}

The mass media has several very important functions, including conveying information to audiences or readers. The mass media also has an educational function by presenting and publishing writings that are educational for its readers. In the context of the research that the author has carried out, several roles of the media are found in the implementation of Islamic law and efforts to anticipate the silting of the ummah's aqidah. Some of the roles that were found included:

\section{The Socialization Qanuns on Islamic Sharia}

This role was carried out by the media, especially Serambi Indonesia and the Waspada daily, at the time of the initial implementation of the Qanun in the context of implementing Islamic Sharia. This is a form of socialization carried out by related parties, in this case the Islamic Sharia Service, so that the Qanuns relating to the implementation of Islamic Sharia can be known by the public. In addition to publishing the Qanun in full in the form of advertisements on these two media, the media also contains news about socialization events and seminars on the implementation of Islamic Sharia in Aceh. Journalists Waspada and Serambi Indonesia always make the Socialization of Islamic Law an activity worthy of their coverage and they write the news. In fact, they will also develop news related to this socialization with other relevant news such as conducting interviews with competent parties on the theme of socializing Islamic Sharia to be made news. This proves that the media take a role, especially the role of socialization and delivery of information regarding the implementation of Islamic Sharia from related parties to the community.

According to Jafaruddin, ${ }^{17}$ at the beginning of the implementation of Islamic Sharia, the media took a role mainly in disseminating the implementation of Islamic Sharia itself, especially regarding the socialization of Qanun concerning Islamic Sharia which the public needs to know. Serambi Indonesia itself makes qanuns on the implementation of Islamic Shari'a as news that is considered important and this is the task of journalists in finding and writing news about Islamic Sharia in Aceh. As head of the Serambi Indonesia bureau, he also made the socialization of Islamic Sharia a priority and assigned journalists at the Lhokseumawe bureau to cover and write about this matter. Likewise with Maimun $1,2018$.

17 Jafaruddin, journalist of Serambi Indonesia, interview in Lhokseumawe, September 
Asnawi, ${ }^{18}$ a Waspada Journalist in Lhoseumawe City and North Aceh. According to him, the Waspada Daily, although published in Medan, has made Aceh a productive news area because of the many alert readers who live in Aceh. Islamic law is also a theme that is often a priority for news for editors. It is not uncommon for us to receive special assignments to cover the Islamic Sharia. At the beginning of the implementation of Islamic Sharia, the socialization of Islamic Sharia became news that Waspada's editorial choice to load. This has become one of our enthusiasm for Waspada journalists who work in Aceh, especially in Lhokseumawe and North Aceh, to make news about the socialization of Islamic Sharia as a news choice.

\section{Preaching Heretical Criteria}

In the context of hereticalism, printed media also has a strategic role. Media Serambi Indonesia and Waspada appear to be very active in discussing the emergence of deviant sects which are very disturbing for the community. Both of these media have reported that the criteria which can be used to characterize a sect are considered heretical. This information is of course highly expected by the community to find out whether there are deviant sects around them or not. On the other hand, the publication of news regarding the criteria for deviant sects is one proof that the media is a funnel for information from parties with an interest in disseminating information about these deviant criteria.

For example, the fatwa of the Aceh Ulama Consultative Assembly (MPU) which defines the criteria regarding sects that are considered heretical. Although this information is conveyed through official channels through the bureaucracy to parties deemed important, the loading of the fatwa through the print media, especially the Serambi Indonesia Daily and the Waspada Daily, has provided fast and accurate information services to the public. So that the print media is considered to have a very important role in disseminating the MPU Fatwa on the criteria for deviant sects in society. Zainal Abidin, ${ }^{19}$ a Waspada journalist in Lhokseumawe and North Aceh, said that the issue of heretical sects that occurred in Aceh had become the news of choice in the Waspada daily where he worked. According to him, heretical sect is interesting news because it appears in the middle of the implementation of Islamic Sharia that it is trying to be implemented in Aceh kaffah. For the Waspada media, this is an interesting thing to report, therefore as a journalist he tries to find and write news relating to deviant sects that have occurred in Lhokseumawe and North Aceh because the Waspada editor has prioritized this news.

${ }^{18}$ Maimun Asnawi, journalist of Waspada, interview in Aceh Utara, September 17, 2018.

${ }^{19}$ Zainal Abidin, Journalist of Waspada, interview in Lhokseumawe, September 12, 2018. 


\section{Reporting Violations of the Implementation of Islamic Law}

This is a role that is very much done by the media, especially the Serambi Indonesia Daily and the Waspada Daily. These two media, if we observe the news they contain, we will find news about violations of the Qanun Qanun related to the implementation of Islamic Sharia. The most frequently found news is the violation of Qanun Number 14 of 2003 concerning Khalwat, Qanun concerning Maisir and gambling, and Qanun concerning Syiar Islam (Muslim clothing) as in the news below:

Caned, 3 Convicted Violators of the Qanun Sharia Islam in South Aceh

Tapaktuan (Waspada Aceh) - The Tapaktuan District Attorney (Kejari), executed three convicts of violating Aceh Qanun No. 06 of 2014 concerning the Jinayat law, at the courtyard of the Al-Makmur Mosque, Gampong Lhok Keutapang, Tapaktuan, South Aceh, Friday, (21 / 12/2018).

Each of the convicts who were flogged with the initials HH, a resident of Air Pinang, Tapaktuan Subdistrict, were executed 20 whips in front of hundreds of residents. The judge was found guilty of committing Jarimah Ikhtilath, as stipulated in Article 25 paragraph (1) of Aceh Qanun Number 14 of 2014 concerning the Jinayat law.

Apart from HH, the executor also sentenced JS, a resident of Gampong Peulokan, West Labuhanhaji District.

Meanwhile, TA, a resident of Gampong Lhok Sialang, Kecamatan, Pasieraja, was caned 183 times, for allegedly raping a minor. However, the convict was only able to endure 50 lashes.

South Aceh Kajar Munif, SH, MH, through the Head of Pidum Riki Supriadi, SH, told Waspadaaceh.com that $\mathrm{HH}$ and JS each served 25 lashes.

"After the detention period he had served was cut, the remaining Uqubat Ta'zir became 20 lashes. While TA, the number of lashes is 200 times, the period of detention is cut so that the remaining Uqubat Ta'zir is 183 times, "he explained. (Faisal) ${ }^{20}$

In the daily Serambi Indonesia, many news about violations of Islamic Sharia are also found as below:

Father Goes to See Perverted Child in the Room

SERAMBI, MEULABOH- A perverted perpetrator named Samson (pseudonym) who is still 16 years old, a resident of a village in Kuala Pesisir sub-district, Nagan Raya district, Friday (23/9) early in the morning when a mob was attacked by a mob after being arrested while committing a forbidden act with Flowers (14) The incident that shocked residents in the area occurred when Bunga's father caught them naked in his daughter's room. Seeing his son being 'tilled' by Samson, the father became furious. Samson also received a 'blow gift' from Bunga's father. When Bunga's father emotions

${ }^{20}$ Waspada, Desember 21, 2018. 
grew out of control, residents came and Samson, who was recorded as still in second grade at a vocational high school in Meulaboh City, was also the target of the residents' anger. The Head of Satpol PP and WH of West Aceh Regency, Drs John Aswir, through the WH (Dan Ops) Operation Commander T Abdurrazak told Serambi, said the arrest of the two perverted underage perpetrators occurred when the two were having copulate in the perpetrator's of girls room. Information obtained by Serambi, before the arrest took place, Bunga's father overheard a strange sound from inside his daughter's room at midnight. Feeling suspicious, the father immediately approached the source of the sound and immediately became suspicious with that unusual voice. Before intercourse, said Abdurrazak, the female perpetrator admitted that he was shown a pornographic video so that he was aroused, so he was immediately influenced by an invitation to commit an act that is prohibited in religion. "We have submitted the perpetrators to the investigators at the police, because both of them were also proven to have committed obscene acts and violated Qanun Sharia Islam Number 14 of 2003 concerning khalwat / nasty with the threat of public flogging," he concluded. ${ }^{21}$

\section{Gambling (Lottery) Is Increasingly Prevalent In Peusangan}

Serambi Indonesia, SUNDAY 2 OCTOBER 2011 BIREUEN - Dark toto gambling (lottery) is increasingly prevalent in Peusangan, Bireuen. In fact, the gamblers' action, known locally as the tail, has troubled the people there. Until yesterday, there had not been any special handling from the local police. Kapolsek Peusangan, Ipda Syarifuddin MA said, his party has also received reports from the public about the rampant tail betting in his jurisdiction. "We have currently formed a team to eradicate lottery gambling. We will still arrest whoever the perpetrator, "said Syarifuddin when contacted by Prohaba, yesterday. He emphasized that his party did not remain silent in eradicating all forms of gambling in society. (C38) 22

Three men in Dibeureukah during the Cimeng Party at Kolong Meunasah

LHOKSUKON - Kolong meunasah Biara Barat, Tanah Jambo Aye District, North Aceh, was used as a venue for drug parties. Receiving this information, Saturday (24/9), at around 23.00 WIB, the North Aceh Police Drug Unit (Polres) immediately ambushed the location. Police dexterity left the three men under the meunasah, unable to move anymore. The three of them were arrested (arrested-ed). From the results of the examination, it was found that the three of them had just completed the ritual of the marijuana party under the meunasah. The three men referred to are Abdul Jaban Abdurrahman (32) and Ridwan Abdul Hamid (41), residents of West Biara, Tanah Jambo Aye District, North Aceh. Another person is Mukhlis Ilyas (21), a resident of Rambong Dalam, Baktiya District, North Aceh. Together with the three, evidence was found that a small package of dry marijuana costing Rp.10 thousand, and a package of remaining marijuana had been used by the three suspects. "The results of the urine test showed that the three of them

${ }^{21}$ Serambi Indonesia, September 24, 2011.

${ }^{22}$ Serambi Indonesia, Oktober 2, 2011. 
were positive about consuming marijuana," said the North Aceh Police Narcotics Head, AKP Syafran to Prohaba, Monday (26/9). He added that the West Monastery area, Tanah Jambo Aye District, North Aceh was prone to drug trafficking. "In fact, all this time, we have arrested suspects in the village who are categorized as dealer. We hope that the public will provide information so that it is easy for us to catch drug users and dealers, "asked Syafran. Meanwhile, Abdul Jaban, mentioned that he had consumed marijuana the day before. "Not when he was arrested," said Jaban. Meanwhile, Muklis Ilyas mentioned that he had consumed marijuana four days earlier. However, what is clear is that the police found a package of marijuana and used it when they arrested them. (C46) ${ }^{23}$

At the beginning of the implementation of Islamic law, news about violations of Islamic law was found almost every week in the daily Serambi Indonesia and Waspada. This shows that the implementation of Islamic Sharia cannot be implemented by all elements of society. The most common cases were cases of khalwat or two of men and women who were not their muhrim. The places are still very varied, ranging from boarding houses, salons, and cafes that are open until late at night. It is not uncommon for people to be caught doing seclusion in a parade around the village and being bathed in a meunasah/ musalla. Another common case is maisir (gambling). It is found in various places where it is often used as gambling stalls. Usually, journalists find out about violations of this kind of violation more quickly because they are involved by the Islamic Sharia Service through the Sharia Police (wilayatul hisbah) when they get reports from the public if activities are found that are contrary to the Qanun Syariat Islam such as the Waspada daily report below:

\section{Immoral and Gambling, Six Offenders of Sharia Caning}

Six violators of Islamic law in Banda Aceh were caned because they were proven to have committed obscenity and gambling. The execution at the courtyard of the At Taqwa Mosque, Gampong Lhoong Raya, Banda Raya District, Banda Aceh City, Thursday (24/ 3). The six flogged convicts were Budiman (39 years) from Banda Aceh and Sakdiah (22 years) from West Aceh who were sentenced to 20 lashes minus three lashes. Both were found guilty of perverting. Then, Umar Yusuf (52 years) from West Aceh, Baili (42 years) from Aceh Besar, Bustamam Hasan (32 years) from Aceh Besar, and Rusli (49 years) from East Aceh. They were sentenced to seven lashes minus two lashes for allegedly gambling. The deputy mayor of Banda Aceh, Zainal Arifin, said that the execution of the flogging was not fun because many residents watched while laughing and cheering on the convicted whip. "Even though those who were flogged willingly carry out their punishment as a way of repentance. They regret their actions, "he said, urging residents not to laugh and shout at those who were convicted. "They are not necessarily worse than us. Appreciate those who have sincerely served their sentences. It is hoped that in the future no one will violate Islamic law and be executed with a whip, "hoped Zainal. The deputy mayor of Banda Aceh also emphasized that the execution

${ }^{23}$ Serambi Indonesia, September 27, 2011. 
was a constitutional order of the Republic of Indonesia. Where this punishment is regulated in legislation. It is said, caning is also part of enforcing the law of Allah SWT. "So we don't have to worry about those who argue about caning. The caning punishment is an order of the Law of the Republic of Indonesia, "said Zainal.

For the media, violations against the Qanun regarding the implementation of Islamic Sharia become commercial information to be used as news. Because news about Qanun violations, especially Qanun Khalwat, is very attractive to readers. According to Saiful Bahri, ${ }^{24}$ a journalist for Serambi Indonesia in the city of Lhokseumawe, the many cases of violations of the Qanun Sharia Islam in Lhokseumawe City and North Aceh have become the news reported by the Serambi Indonesia daily. News about seclusion, gambling, and alcoholism were widely covered and written by journalists to send to editors. This is interesting because the violation of the Islamic Sharia qanuns occurred in the midst of the enthusiasm of the Aceh Government in implementing regulations regarding seclusion, gambling and drinking, including the rules for dressing Muslim and Muslimah. However, many of these rules are still being violated by the community, so that there are still frequent incidents of violations of the Syarait Islam qanun qanun which later became the object for coverage by news hunters in Lhokseumawe and North Aceh to be sent to the editor in Banda Aceh.

\section{Reporting the Community's Rejection of the Emergence of a Cult}

In addition to news about Qanun violations, the Serambi and Waspada media also reported on the phenomenon of public rejection of the emergence of deviant sects. This proves that a cult has no place in society. So that when there are incidents about schools that cause unrest for the community, open rejection often occurs. This rejection can be seen from the mass action carried out by the community after knowing that there were members of the community who were involved in a cult. An example is the news story below:

The Government has been Urged to Disband Millata Abraha

BANDA ACEH - Thousands of protesters, this afternoon, urged the Aceh Government and law enforcement officials to crack down on and disband the cult that has developed in the province, especially the "Millata Abraham" teaching community. About 12 thousand protesters came to the Aceh governor's office on Jalan T Nyak Arief, Banda Aceh City, Thursday at around 09.30 WIB. They staged a peaceful demonstration in the yard of the government office, under tight guard from the local police and Satpol PP. Participants in the peaceful demonstration demanded a firm stance from the government against this cult, among others being carried out by students, junior high school students, Aceh santri organizations (Thaliban), and Acehnese youth and women's communities.

${ }^{24}$ Saiful Bahri, Journalist of Serambi Indonesia, interview in Lhokseumawe, September $1,2018$. 
The action of tens of thousands of people previously gathered at the courtyard of the Al-Makmur Lampriet Mosque, which attracted the attention of the people of Banda Aceh City. On the front page of the governor's office, the protesters carrying various banners and posters denounced the efforts of apostasy and the development of a cult, especially "Millata Abraham" which has poisoned the younger generation of Muslim communities in the area. Tgk Riyandi, a protester from the Aceh Thaliban organization, hopes that the government and police will act quickly to deal with people who have spread a cult believed to be not only "Millata Abraham". "We will support the efforts of the government and law enforcement to crack down on the suspects who have spread the 'Millata Abraham' sect. We hope that the perpetrators of spreading heretical beliefs are punished as severely as possible, "he said. Meanwhile, one student stated that the government was responsible for preventing the development of deviant sects in Aceh. "The government should not allow deviant sects to be spread to us (youth). The proof is that there are students who are influenced by a cult like "Millata Abraham". Therefore, we hope that the government will take firm action against these cult leaders, "he said. Despite the scorching sun, tens of thousands of protesters did not budge from the front yard of the Aceh governor's office. Meanwhile, Aceh Governor Irwandi Yusuf when approaching dozens of protesters expressed his commitment to take steps to prevent the development of deviant sects in Aceh, through a Governor Regulation (Pergub). Apart from Irwandi Yusuf, Deputy governor Muhammad Nazar was also present at the podium the protesters had prepared. ${ }^{25}$

Heresy: Thousands of People Rampage in Plimbang and Pandrah

BIREUEN - A mass riot involving more than 1,000 people occurred in Jambo Dalam Village, Plimbang and Lhok Mane Villages, Pandrah District, Bireuen Regency, Sunday and Monday (21/3) in the morning. During the action, the masses burned three motorbikes (sepmor), a car, and two prayer centers. The mob also threw stones at and damaged two houses, each of which was occupied by a recitation teacher in villages in Plimbang and Pandrah Districts. In fact, the crowd had moved to another sub-district, namely Peudada, at around 04.00 WIB, but because the people they were looking for were not present, they finally dispersed. In the midst of this troubled situation, Bireuen Police personnel acted swiftly. They succeeded in rescuing eight people who had the opportunity to become targets of mob rage, because they were suspected of belonging to a cult. To save the eight people who were threatened with their lives, the police were forced to fire several shots into the air to disperse the crowd.

Based on information compiled by Serambi, last Monday, the residents' anger was triggered by the unfriendly attitude of Tgk Aiyub, one of the recitation teachers in Jambo Dalam Village, Plimbang. Tgk Aiyub is described as an exclusive person (likes to live alone and isolates himself from the interaction of the outside world). The residents suspected that the place for his recitation was a place to teach heretical teachings. In addition, many outside guests who came to Tgk Aiyub's house seemed to ignore the

${ }^{25}$ Harian Waspada, April 7, 2011. 
appeal of the village apparatus. One of the points of appeal for the village apparatus was that anyone who entered the village, including Tgk Aiyub's house, was obliged to report. That was the manners, until last night Tgk Aiyub's house had guests, namely Syarifuddin, the village secretary, along with three other residents. They came to the house around 20.30 WIB. The arrival of the village apparatus disturbed Tgk Aiyub. He rushed out of the room and immediately said rude to his guest. Finally, a small commotion was inevitable. The guest finally failed to enter, because the host did not want to. A few minutes later, the news about Tgk Aiyub's refusal to visit the village apparatus quickly spread throughout the village. The news was peppered with additional information that Tgk Aiyub was spreading heretical beliefs. Spontaneously, it was not clear who was coordinating, almost all residents of Jambo Dalam Village moved to Tgk Aiyub's house which is located south of the Medan-Banda Aceh national road section. Residents from other villages in the sub-district also joined.

The crowd, numbering in the thousands, were screaming for the owner of the house to get out. Seeing the unfavorable signs, the arrival of the masses from almost all villages in Plimbang sub-district was immediately anticipated by the ranks of the Plimbang Police Post, Jeunieb Polsek, Juli Polsek, and Bireuen Polres. Dozens of police officers immediately moved to the village and tried to calm the residents. However, the officers' appeal was in vain. The crowd continued to push Tgk Aiyub's house. At the same time, the police must be more alert to secure Tgk Aiyub and his colleagues, when a physical clash is about to occur. Fortunately, a number of police were able to get into Tgk Aiyub's house early. But immediately Tgk Aiyub's house was showered with stones. Shouts of scorn also sounded blaring. Whoever started it, suddenly two motorbikes in front of Tgk Aiyub's house were pulled out and burned by the crowd. A car was parked in the yard of the house under its tires, then they pushed it and finally set it on fire. A recitation center next to the victim's house was also burned. However, hundreds of books were transferred by Tgk Aiyub students to the nearest kiosk.

Ironically, the masses kept shouting "Kill Tgk Aiyub" because it was claimed that the residents were teaching heretical teachings to their students. Stone throwing at the victim's house continued until 01.00. In this precarious situation, the police officers managed to issue Tgk Aiyub with students and friends at around 01.30 WIB, considering that the house was constantly surrounded by residents from all over the place. Those who took part in the rescue mission of Tgk Aiyub cs included the Head of Plimbang Anisah, the Bireuen Police personnel and village officials. After being released from the house, Tgk Aiyub was immediately put on the police car and rushed to the Bireuen Police Headquarters. ${ }^{26}$

\section{House to House}

Zainuddin, Wisbar and Iqbal who were met at the Banda Aceh Police Headquarters denied allegations that they were involved in developing heretical teachings. According to Zainuddin, the teachings they have carried out so far still refer to the Koran and hadith.

${ }^{26}$ Serambi Indonesia, Maret 22, 2011. 
It's just that, continued Zainuddin, the community was suspicious because it was carried out closed door from house to house. "Is it because I gave religious lessons from house to house, then there was an suspicion that I was developing heretical teachings. I don't think there is any deviant doctrine that I teach. But I admit that there has been a different understanding, especially the residents who have attended Islamic religious lessons with me, perhaps from that it emerged that I was developing heretical teachings, "said Zainuddin. Zainuddin admitted that he continued to pray five times a day and all his teachings to around 40 people who have joined the Millah Abraham Community. "We still refer to the Koran and hadith. The Millah Abraham or Komar community is only in name, there is no heretical teaching that we teach like that accusation, "said Zainuddin.

\section{The Crowd Came}

At around 17.45 WIB, Friday (1/4), the Deputy Mayor of Banda Aceh, Illiza Sa'adudin Djamal, came to the Banda Aceh Police Headquarters. Simultaneously with Illiza's presence, 30 groups of mobs also came demanding that the police not release the three residents who were suspected of developing this cult. Illiza, who was asked by Serambi regarding the defense of the three residents accused of developing heretical beliefs, stated that regardless of whether they wanted to confess or not, what was certain was that a number of witnesses and concrete data showed that they developed heretical teachings starting from pictures, recordings, and others. Even a number of youths who had joined the sect also gave testimony. "There is no need to argue with them anymore because it only consumes energy. But all those accused are because there is evidence, witnesses and other data. It all supports and can be proven that they are really developing heretical teachings, I think that's enough, "said Illiza. The chairman of the Banda Aceh City PGRI, Khairurrazi MPd, representing the community along with 30 mass groups who came to the Banda Aceh Police Headquarters on Friday afternoon asked the police not to release the three residents who were claimed to have developed heretical teachings from the Millah Abraham sect. (Mir). ${ }^{27}$

In order to avoid public unrest, the media must provide insight through interviews with scholars and religious figures including academics about the currents that are developing in society. Although there is no authority for the media to convict, whether the sects that appear in society are deviant or not, by conducting interviews with ulama and being asked for their opinions, the role of the media in this case will provide positive information in terms of the flow of currents developing in Public.

For the media, such news stories identify and inform readers that this cult is not accepted by society. This is certainly one of the most important roles played by the media in providing readers with a correct understanding of heretical sects. By knowing the characteristics of a deviant sect through the MPU Fatwa which is informed through the media, the public will more quickly identify and clarify if there are deviant sects in their

${ }^{27}$ Serambi Indonesia, April 2, 2011. 
environment. So that cases of the presence of deviant sects can be developed into several news sections and can be loaded in several days with different members. Maimun Asnawi, ${ }^{28}$ Waspada journalist in Lhokseumawe, said that when heretical sects entered Aceh, the community often rejected them. Those who disagreed with the entry of deviant sects into Aceh objected in a clear manner, and this is an interesting incident to report on. For the editor of the Waspada daily, this is also news that deserves to be loaded and becomes a priority, the proof is that news sent with this theme is always published.

\section{The Comments Contains of Figures on the Implementation of Islamic Sharia and Efforts to Banish Aqidah}

This role is the role of the socialization of policies and responses to policies as well as problems that arise in the context of implementing Islamic Shari'a and Efforts to Shallow Aqidah. Along the way, it find many in Serambi Indonesia and the Waspada Daily, news reports containing comments from figures and experts in their respective fields regarding the implementation of Islamic Sharia and efforts to anticipate the silting of the ummah's aqidah. For example, we find the Governor's comments about the prohibition of entry to deviant sects, comments from the Chairperson of the Aceh Ulama Consultative Council (MPU) and districts/cities in Aceh regarding deviant sects and the Head of the Islamic Sharia Service on matters relating to the implementation of Islamic Sharia. The news stories below show the existence of these roles:

The Governor's Regulation on the Prohibition of Cults was Published

BANDA ACEH - To stem the spread of deviant sects in Aceh, such as the Millata Abraham sect, Governor Irwandi Yusuf on April 6 issued Governor Regulation (Pergub) Number 9 of 2011 concerning the Prohibition of Activities of the Millata Abraham School in Aceh. With the issuance of this Pergub, the teachings of Millata Abraham or the Millata Abraham Community (Komar), may no longer be disseminated in the jurisdiction of Aceh. Governor Irwandi emphasized this in his speech at the Peace Demonstration Against Heretical Sects which took place in front of the Aceh Governor's Office, Thursday (7/4) morning.

The governor said that the aims and objectives of the issuance of the governor's regulation were, among others, to maintain public security and order from any conflicts caused by the spread of deviant religious views. Likewise, the public is prohibited from committing anarchist actions and/or acts against the law related to the activities of followers, members and/or administrators of the heretical sect Millata Abraham (Komar) who deviate from the faith and Islamic law and/or other religions. The handling of the activities of followers, members and/or administrators of the Millata Abraham sect that deviates from the faith and sharia of Islam and/or other religions, is carried out by authorized

${ }^{28}$ Maimun Asnawi, Journalist of Waspada, interview in Aceh Utara, September 17, 2018. 
officials in accordance with the provisions of the applicable laws. The governor added, to eradicate this cult, the role of the community is highly expected. People who are aware of Millata Abraham's activities in the form of dissemination, interpretation, and activities that deviate from the Islamic faith and or other religions that are contrary to the Governor Regulation, are obliged to report to the police apparatus and/ or other authorized agencies. Meanwhile, for those who violate Pergub Number 9 of 2011, the Aceh Government has the authority to stop the activities and/ or activities of followers, members and or administrators of Millata Abraham (Komar). Adherents, members and / or administrators of the Millata Abraham sect and/ or who do not heed this regulation, will be subject to sanctions in accordance with the provisions of laws and regulations. As for handling and preventing the spread of this cult, said Irwandi Yusuf, it is not only the authority of the provincial government, but also regents/ mayors need to determine operational steps in handling the Millata Abraham sect in districts/ cities within Aceh Province. The regent/ mayor is required to report the handling of the Millata Abraham (Komar) sect in their respective districts/ cities to the Governor of Aceh.

\section{Cooperative Decision}

The Head of the Aceh Kesbangpol \& Linmas Agency, Drs H Bustami Usman MSi and the Head of the Aceh Secretariat's Legal and Public Relations Bureau, Makmur Ibrahim MH said that the policies taken by the Aceh Government in dealing with deviant sects, not only issued Pergub Number 9 of 2011, but also issued joint decisions for the same. The joint decision was signed by the Governor of Aceh, the Commander of the Iskandar Muda Military Command, Maj. Gen. Adi Mulyono, the Head of Aceh Regional Police, Inspector General Pol Iskandar Hasan, Kajati Aceh Muhammad Yusni MH, and the Head of the Regional Office for the Ministry of Religion of Aceh, Drs Abdurrahman TB Lt.

The head of the Aceh Kesbangpol \& Linmas Agency said that according to his observations the Millata Abraham sect had spread to various jurisdictions in Aceh. Not only in the east-north coast of Aceh, such as Bireuen, Aceh Besar, and Banda Aceh, but it has reached the west and south coasts of Aceh. The number of congregants who are referred to as the "Mukmin Mubalig" has even reached 700 people.

The target of its distribution is more to young people. This is evident from the number of adherents obtained by Kesbangpol \& Linmas Aceh that many of the alumni of superior schools, among others, are from superior high schools and model MANs in Aceh. The Aceh Government prohibited the Millata sect, because it is against Islamic law.

Bustami Usman suspects that the number of deviant sects will continue to grow. The name of the sect can be changed to get rid of traces of his heresy Tariqat Naqsabandiyah Prof. Dr. H Kadirun Yahya which is located in Mandala Village, Kutacane, Southeast Aceh, this sect is still being researched and studied in depth.

But for the Tariqat Nadsyabandiyah Mujahiddinyah Khalidiyah, it is permissible. "For that, people need to be aware of their environment from religious teachings that smelled of Islam or other religions that lead to heretical and misleading teachings. If there is, immediately report it to the security apparatus and the local MUI so that legal action is taken, "said Bustami Usman. 


\section{Strengthened of Qanun}

The Chairman of the Aceh MPU, Prof. Dr. Tgk Muslim Ibrahim MA strongly supports Governor Regulation Number 9 of 2011 concerning the Prohibition of Activities of the Millata Abraham School in Aceh which was published on April 6, 2011. But he is of the view that the regulation must be strengthened by qanuns, including sanctions regulations against those who join in the stream.

"If it has been regulated in a qanun, then the power of law is stronger and will continue as long as the qanun is not revoked. Meanwhile the governor's regulation is only valid for a year and can be extended a year later. Therefore, we support the rules regarding the issue of what sect is deviant and misleading and strengthened by qanuns, "said Tgk Muslim in response to Serambi yesterday.

According to Tgk Muslim, the legal rules regarding deviant sects have been regulated in Qanun No.11 of 2002 concerning the Implementation of Islamic Sharia in the Field of Akidah and Sharia. The sanctions in the qanun include, among other things, propagators of deviant sects being punished with 12 lashes or a year imprisonment. Meanwhile, the rules in the Criminal Code are even heavier. The maximum threat is five years in prison.

However, Tgk Muslim supports the issue of deviant sects, especially in Aceh, which is regulated in a new qanun in order to strengthen the governor's regulation, including that sanctions against acts of insulting religion are made again so that similar acts are not repeated.

Meanwhile, in the MPU NAD fatwa Number 4 of 2007 concerning Guidelines for the Identification of Heretical Sects, it does not regulate sanctions against propagators and followers of deviant sects, but regulates the criteria for deviant sects.

The Aceh MPU Fatwa states 13 criteria for deviant sects, including denying one of the pillars of faith and pillars of Islam, believing and/ or following a creed that is not in accordance with the intentions of Ahlussunnah wal Jamaah, and believing in the revelation after the Koran, denying the purity and/ or truth of the Koran.

"So, whatever the name of the sect, if it falls among the 13 criteria, then according to the MPU Fatwa, it is a deviant sect, and can be legally processed according to legislation," said Tgk Muslim.

\section{The Right Step}

Kajati Aceh, Muhammad Yusni SH, as the head of the Team for Monitoring Community Beliefs (Pakem) in Aceh, welcomed Governor Irwandi Yusuf's move to immediately issue a Governor Regulation concerning the Prohibition of 14 Religious Sects that were Considered Heretical. "This is the right step for the Governor of Aceh to take, so that law enforcement officials do not hesitate to act to ban this cult," he said.

In fact, his party as the head of the Aceh Pakem Team has sent a report to the Attorney General (as the head of the Central Pakem Team) regarding the 14 deviant sects currently operating in Aceh. This step was taken to inform the central government about the existence of deviant sects in Aceh, so that if these currents also exist in other areas, they 
will be immediately dealt with. "Of course, a national ban can only be carried out after a decision has been made from the Central Pakem Team," he said. (sal/ her/ soup) ${ }^{29}$

The Aceh Government Bans 14 Deviant Sects

The Aceh Musspida together with the Aceh Ulama Permusyaratawan Council (MPU) stated that for the time being there were 14 religious schools operating in Aceh that were prohibited and had to be closed because they were proven heretical and misleading.

This statement was conveyed by the Governor of Aceh, Irwandi Yusuf to the press after the Aceh Muspida meeting with the Aceh MPU to make a decision to stipulate the prohibition of deviant sects in Aceh. The meeting took place in the Aceh Governor's office, Wednesday (6/4).

"For example, the teachings of Millata Abraham, which were found in Peusangan District, Bireuen, after conducting research and studies by the MPU and the Aceh Muspida, were included in the category of deviant and misleading beliefs, so they are prohibited and must be closed immediately," said Irwandi Yusuf accompanied by the Military Commander Iskandar Muda. Maj. Gen. Adi Muliono, Aceh Police Chief Inspector General Pol Iskandar Hasan, Kajati Muhammad Husni, MPU Chair Prof. Dr. Muslim Ibrahim, Prof. Dr. Rusdy Ali Mahmud, Head of Kesbang Polinmas Aceh, Drs H Bustami Usman MSi and other related officials.

According to Irwandi, the decision to ban and close the teachings of a belief will be outlined in a Governor Regulation (Pergub). This will serve as a legal umbrella by the Provincial Government, Regency/ City Government, and other vertical law enforcement agencies to take action against the perpetrators of spreading the misleading belief of this cult.

For example, to the propagator of the heresy of Millata Abraham. According to information, this heretical teaching comes from the heresy of Ahmad Musadek, which had previously occurred in Java. The teachings are very similar and according to the criteria for heretical teachings published by the Aceh MPU, they fall into the category of heretical teachings. "So, the MPU and the Aceh Muspida carried out the categorization of heretical teachings after conducting in-depth studies and research. If the flow is Islamic, the criteria for sharia and Islamic laws are used in the Koran and the hadiths of the Prophet, "said Irwandi Yusuf.

Irwandi said, the most effective prevention of heretical teachings is from the family environment. Parents must be more sensitive to changes and religious education and their children's beliefs.

Because, said the governor, many clever children in the city of Banda Aceh fell into a cult of heretical teachings, one of the reasons was because the faith taught to children was not deep, so that when other people invited and according to them the teaching was logically acceptable, then directly embracing these teachings. "This needs to be watched out by all parties," said the Governor of Aceh.

${ }^{29}$ Serambi Indonesia, April 8, 2011. 
Aceh Police Chief Inspector General Pol Iskandar Hasan emphasized that if he refers to the Criminal Code, spreading the teachings of a misleading belief can be sentenced to five years. However, before law enforcement steps are taken, first the disseminators of his teachings are secured so that no casualties occur. Furthermore, his teachings were prohibited and was followed by closing down the activity venue.

Kapolda gave an example of Millata Abraham's teachings in Peusangan District, Bireuen. The total number of members in Aceh is around 700 people. The perpetrators who spread the teachings had been secured and after the Governor of Aceh issued the governor's regulation, it was continued with the next legal steps. "Pergub is needed as a legal umbrella for local government officials and law enforcers to process the perpetrators of spreading heretical teachings," said the Aceh Police Chief.

\section{The Funders}

The Aceh Police Chief said the police were also investigating funders for deviant sects. Because previously, Aceh Deputy Governor Muhammad Nazar revealed that every follower of a cult (Millata Abraham) was paid Rp. 15 million a month.

"Various parties continue to monitor Millata Abraham's movement, including his followers. So, based on the findings of Islamic Organization Inshafuddin, everyone who joins the Millata Abraham sect is paid Rp. 15 million a month, "Deputy Deputy Muhammad Nazar told reporters after chairing a special meeting to follow up on deviant sects in Aceh, Tuesday (5/4).

Responding to the signal of money playing in the spread of this cult, the Aceh Police Chief said that heretical teachings could rapidly develop in Aceh, first because after the tsunami this area was very open to all sects and groups carrying out humanitarian missions, both from within and from abroad. Another supporting factor, the source of the funds is quite strong. This can be seen from the method or methodology of spreading heretical teachings that are misleading in recruiting followers, one of which is by giving money to the target members who will be recruited.

\section{Streams Previously}

Head of the Aceh National Unity and Community Protection Agency, Drs Bustami Usman said, from the results of the evaluation, research and study of the Aceh MPU and Muspida, initially there were 17 schools of thought that were considered heretical. However, after the research was conducted again, the remaining 14 teachings were categorized as heretical, while three more were not included, among them the Naqsabandiah Tariqat, the Indonesian Islamic Da'wah Institute (LDII), and the other one was not evaluated because it was closed, namely Dayah Ruhul Aceh.

Besides that, said Bustami Usman, there are still four more heretical teachings that are suspected of being heretical and need to be studied and studied in depth, namely the teachings of Salik Budha, the teachings of Sukardi, Mukmin Mubalik, and the alleged banishment of aqidah in Simeulue. "If the results of the research and study later fall into the criteria of heretical teachings that are misleading, the Aceh Government will 
immediately issue a Governor Regulation to prohibit and close down places of activity or houses of worship," said Bustami Usman. ${ }^{30}$

\section{The Aceh Government Bans 14 Deviant Sects}

BANDA ACEH - As many as 14 schools of belief operating in Aceh are prohibited and must be closed, because they have been proven heretical and misleading. Like the Millata Abraham sect which was found in Peusangan District, Bireuen, after a research and study was carried out by the MPU with the Aceh Muspida, it was categorized as a deviant sect. The Governor of Aceh, Irwandi Yusuf, said that the decision to ban and close the teachings of a belief would be outlined in a Governor Regulation (Pergub). This will serve as a legal umbrella for provincial, district and city governments, and other vertical law enforcement agencies to take action against perpetrators of heretical teachings. "This heretical teaching comes from the heretical teachings of Ahmad Musadek which previously occurred in Java. The teachings are very similar and according to the criteria published by the Aceh MPU, these teachings fall into the category of heretical teachings. So, the MPU and the Aceh Muspida have classified them after conducted in-depth studies and research, "said the governor, this morning. Irwandi said, the most effective prevention of heretical teachings is from the family environment. Parents must be more sensitive to changes and religious education and their children's beliefs. Because, many clever children in the city of Banda Aceh fall into a cult of heretical teachings, one of the reasons is because the faith taught to children is not deep. So, when there are other people who invite and according to them the teaching can be logically accepted, then they immediately embrace the teaching. "This needs to be watched out by all parties," said the governor. ${ }^{31}$

\section{DII: Announce Heresy}

BANDA ACEH - The Banda Aceh Islamic Da'wah Council (DDI) asked the Ulama Consultative Assembly (MPU/MUI) to name the organizations that have developed deviant sects in the province. "We consider the criteria for deviant sects that the Aceh MPU has insufficient. Therefore, it is necessary to announce the names of organizations that develop deviations from Islam," said Secretary of the Banda Aceh City DDI Wirzaini Usman in Banda Aceh. Mirzaini Usman said that if the MPU and the government only mentioned the criteria without mentioning the names of the organizations, it was feared that the public would draw their own conclusions about this misleading teaching. In addition, DDI Kota Banda Aceh also considered that the Aceh governor's regulation (Pergub) was not sufficient to anticipate deviant sects developing in this area if they were not strengthened by a Qanun (Perda).

Meanwhile, Governor Irwandi Yusuf has issued Pergub Number 9 of 2011 concerning the prohibition of the activities of the "Millata Abraham" sect in his area. Chairman of the Teachers Association of the Republic of Indonesia (PGRI) Aceh, Ramli Rasyid, urged the Aceh Government to immediately eradicate all forms of activities that deviate from Islamic aqidah throughout Aceh. "We also urge adherents of the cult" Millata Abraham

\footnotetext{
${ }^{30}$ Serambi Indonesia, April 7, 2011.
}

${ }^{31}$ Harian Waspada, April 8, 2011. 
"and the like to return to the correct teachings. If they don't want to, they will immediately leave Aceh," he added. The Chairperson of the PGRI also urged the Aceh Government to instruct the ranks of government and non-government in Aceh to carry out intensive, coordinated and sustainable guidance and strengthening of Islamic aqidah to its employees. Meanwhile, Deputy Secretary General of the DPP Al Ittihadiyah H Muchlis Arsyad supported the efforts of elements of Acehnese society to encourage the government and legislature to make Qanuns to anticipate deviant sects and silting aqidah. "The problem of heretical sect cannot be allowed to grow because it has broad implications for damaging the aqidah of Muslims. The efforts made by the Acehnese people to fortify their people from the influence of deviant sects must be supported," he explained. ${ }^{32}$

\section{HUDA: Determination of Deviant Sect from the MPU Fatwa}

BANDA ACEH - Secretary General of the Aceh Dayah Ulama Association (HUDA) Tgk Faisal Ali stated that to determine whether a sect is deviant or not must pass a fatwa from the Regional Ulama Consultative Assembly (MPU/ MUI). "This means that if the government wants to announce that a sect is deviant or not, it must refer to the MPU fatwa, so that the public will not be mistaken in receiving the information," he said in Banda Aceh, Thursday. The government, he added, has the function of carrying out the fatwa that has been decided by the MPU so that it does not cause misinterpretation and confusion in the community, especially Muslims in the province.

On the other hand, Faisal Ali, who is also the Chairman of the Aceh Regional Nahdatul Ulama (PWNU) leadership, asked the Aceh government and legislature to immediately issue a Qanun (Perda) on the prohibition of developing deviant sects in this Muslimmajority province. "The Qanun also needs to regulate the form of legal sanctions for anyone spreading heretical and misleading sects and their followers in Aceh. We expect stricter and heavier legal sanctions to those who spread deviant sects in Aceh," he explained. Meanwhile, Chairman of the Aceh Rabithah Thaliban Board (RTA/ santri organization) Tgk Hasbi Albayuni, also urged the Aceh Government to implement the Joint Ministerial Decree (SKB) and Law No.5/ PNPS 1969 concerning the prevention of religious abuse and blasphemy. In addition, he also urged the Aceh Government to implement Qanun No. 11/2002 on the implementation of Islamic Sharia articles 4 and 5, as well as MPU fatwa No. 4/2007 on the criteria for deviant sects.

Tgk Hasbi also urged the Aceh Government to immediately form a special team to investigate heretical sects and the silting of aqidah that have occurred in the far westernmost province of Indonesia. Another effort, he added, also asked the Aceh Government to instruct the district/ city and sub-district governments to make banners against heretical beliefs and silencing aqidah. "The role of figures and communities in (village) gampongs is very strategic to carry out sterilization so as not to let deviant sects enter this area. I also urge the public not to act anarchically if people are suspected of broadcasting heretical teachings," he added. ${ }^{33}$

\footnotetext{
${ }^{32}$ Harian Waspada, April 8, 2011.

${ }^{33}$ Harian Waspada, April 7, 2011.
} 
Comments from figures from both the government and religious organizations like that are also a funnel for related institutions to provide a correct understanding for the community about the implementation of Islamic Sharia and efforts to overcome the silting of the ummah's aqidah. they found that there were problems relating to the implementation of Islamic Sharia and countering efforts to deny the ummah's aqidah. With the role of the media like this, it will greatly assist the community in increasing their understanding.

\section{Mass Media Constraints in Anticipating Efforts to Silence Aqidah}

From the research that the author has carried out, it is revealed that in carrying out the task of carrying out coverage, especially in writing news related to the implementation of Islamic Sharia and efforts to reduce the aqidah, several obstacles are encountered by the media. In general, they can still carry out their journalistic activities and convey information about the implementation of Islamic Shari'a and the efforts to reduce the Aqidah of the ummah to readers quickly and accurately. Zainal Abidin, ${ }^{34}$ a Waspada journalist in Lhokseumawe, said that the media can at any time coordinate with related parties to obtain statements, clarifications or explanations regarding the implementation policy of Islamic Sharia or even efforts to suppress the ummah's aqidah.

In disseminating information about the implementation of Qanuns related to the implementation of Islamic Sharia, sometimes they also experience a few obstacles. From the internal side of the media, for very vulgar news, especially for the Khalwat case, the media editorial policy varies. There are those who think that the news about the arrest of the khalwat perpetrators is news that will make headlines and increase print circulation. However, there are also editors who consider the news with media policies in the context of decency. Because news regarding the violation of Islamic Sharia is not only read by the people of Aceh, but will be read by people in other areas.

In addition, Zainal continued, terror and threats often haunt the media when reporting incidents of Islamic Sharia violations. They experience this when they report incidents of violations of the Qanuns on the implementation of Islamic Sharia, be it Khalwat, Maisir and Khamar. It is not infrequently, the perpetrators or the families of the perpetrators of the Qanun violations who were arrested warned the media not to publish what they experienced. For this reason, not infrequently, in the news that will be written, journalists are forced to hide the identity of the perpetrators of the violation of the Qanun Sharia Islam that occurred to prevent unwanted things from happening to them.

The lack of journalists' knowledge of the rules contained in the Qanun is also an obstacle in itself for the media in reporting on the implementation of Islamic Sharia in Aceh. Many journalists did not know the full contents of the Qanun and thus influenced

${ }^{34}$ Zainal Abidin, Journalist of Waspada, interview in Lhokseumawe, September 12, 2018. 
their reporting. Journalists do not understand the name and number of the Qanun correctly, so they only write about the violation of the Qanun Khalwat, gambling and liquor in the news. In fact, the qanuns have been arranged in an orderly manner, complete with numbers, years and what they were made about. However, because most journalists do not understand this, most of them only write violations of the Qanun Khalwat, gambling and liquor in the Indonesian language. Whereas the Qanuns on Islamic Sharia, the language is adopted from Arabic such as Khalwat, Maisir and Khamar. ${ }^{35}$

Another opinion was conveyed by Maimun, Waspada journalist in North Aceh. According to him, in carrying out coverage, especially news of the implementation of Islamic Sharia and the efforts to suppress the Aqidah of the ummat, he did not experience any significant obstacles. Communication and friendship with parties related to the implementation of Islamic Sharia has been carried out well. However, for the news about the efforts to shallow aqidah, his party sometimes encountered problems. The constraints referred to include the difficulty in finding direct confirmation from the perpetrator who is accused of spreading heretical beliefs or from people who report the existence of deviant sects in society. Journalists have problems getting direct information from people who have been accused of spreading heretical beliefs. This of course reduces the level of public trust in the news they write. This is because the media is unable to provide confirmation and clarification regarding news related to them. ${ }^{36}$

Another experience was conveyed by Jafaruddin, ${ }^{37}$ a journalist from Serambi Indonesia, who also said that in covering the news about the implementation of Islamic Sharia and heretical sects, they also experienced several obstacles. Among them are the rules to hide the identity of news sources who are still minors. This is often experienced when there are children who are arrested in several cases such as cases of obscenity and gambling. In addition to identity, journalists also find it difficult to take photos of the perpetrators of violations. They cannot freely take photos showing the faces of the perpetrators. Journalists usually take photos from behind or from the side of the victim or perpetrator so that it will slightly disrupt the work process of reporting the news.

Another obstacle, according to Jafaruddin, ${ }^{38}$ is the existence of terror and threats in the form of prohibiting writing and publishing news related to other parties. This happens, if there is an arrest incident of the perpetrator of the violation of the Islamic Sharia Qanuns. It is not uncommon for the victims who were arrested to forbid and threaten journalists not to share what happened to them in the newspapers. Intimidation sometimes also comes from victims' families who have social status and positions in various institutions.

${ }^{35}$ Ibid.

${ }^{36}$ Maimun Asnawi, Journalist of Waspada, interview in Aceh Utara, September 17, 2018.

${ }^{37}$ Jafaruddin, Journalist of Serambi Indonesia, interview in Lhokseumawe, September $1,2018$.

${ }^{38}$ Ibid. 
In reporting the news of efforts to suppress aqidah, journalists also encountered obstacles, including the difficulty of obtaining confirmation from parties accused of spreading heretical beliefs. This is because usually the accused perpetrators usually seem more closed and close themselves to meeting with other parties, especially journalists. They are very difficult to meet, let alone interviewed, even though journalists really need their confirmation and clarification of the allegations that have been addressed to them. However, in practice, these actors are very difficult to find, so that journalists experience difficulties in writing balanced news as required by the Journalistic Code of Ethics. ${ }^{39}$

\section{Conclusion}

The role of Serambi Indonesia and Waspada media in the implementation of Islamic law and efforts to suppress aqidah is considered strategic to socialize Islamic Sharia qanuns in Aceh. This media also framed news about violations of Islamic Sharia as an effort to carry out a social control function of government programs in implementing Islamic Sharia in Aceh. These two media became a reference for the people of Aceh in assessing the process of implementing Islamic Sharia and silencing the aqidah of the people in Aceh. News about the implementation of Islamic Shari'a and efforts to suppress the Aqidah of the ummat were found in the Serambi Indonesia and Waspada daily newspapers. In addition to educating readers about the information on Islamic Sharia qanuns, this media also reports on the execution of sanctions for violators of Islamic Sharia as a deterrent effect received by the community against violations of the Islamic Sharia qanuns in Aceh. The obstacles faced by the media in reporting on the implementation of Islamic Sharia and efforts to suppress the Aqidah of the ummat include terror or intimidation for not reporting the news; must hide the identity of the perpetrator if he is a minor; and the difficulty of confirming and clarifying with sources/ perpetrators, both perpetrators of Islamic Sharia violations and deviant sects. The dream of constructing news on violations of Islamic Sharia in the Serambi Indonesia and Waspada media is expected to minimize violators of Islamic Sharia in Aceh. Public opinion regarding the implementation of Islamic Sharia and the silting of aqidah in Aceh will be influenced by the news it consumes. Coverage of violations of Islamic Sharia and the denial of aqidah can become a reference for the community and government in an effort to strengthen the implementation of Islamic law and counteract the silting of the aqidah of the people in Aceh.

\section{References}

Adhitama, Tias Satrio. "Kartun Humor dan Misi Dakwah dalam Media Cetak," in Jurnal Komunikasi Islam, Vol. 04, No. 01, Juni 2014.

${ }^{39}$ Saiful Bahri, Journalist of Serambi Indonesia, interview in Lhokseumawe, September $1,2018$. 
Al Juanda, et al. "Penerapan Syariat Islam di Aceh dalam Konstruksi Pemberitaan Media Nasional: Studi Komparatif Terhadap Pemberitaan Republika Online dan Okezone," in Jurnal Ilmiah Mahasiswa FISIP Unsyiah, Vol. 1, No. 1, Januari 2017.

A. Kolosova, Alevtina and Deilami, Fatemeh. "Globalization, Culture, and the Role of Media," in Jurnal Journal of International Scientific Publications: Media and Mass Communication, Vol. I, 2012.

Akil, Muhammad Anshar. "Regulasi Media di Indonesia: Tinjauan UU Pers dan UU Penyiaran," in Jurnal Dakwah Tabligh, Vol. 15, No. 2, Desember 2014.

Bakti, A. Faisal. "The Integration of Dakwah in Journalism: Peace Journalism," in Jurnal Komunikasi Islam, Vol. 5, No. 1, Juni 2015.

Darmadi. "Etika dan Profesionalisme Wartawan Serambi Indonesia dan Rakyat Aceh Dalam Peliputan Pelanggaran Syariat Islam di Provinsi Aceh," in Konfrontasi: Jurnal Kultur, Ekonomi dan Perubahan Sosial, Vol. 4, No. 2, Juli 2017.

Troy, Elias. et al. "Media Use, Cross-National Samples, and the Theory of Planned Behavior: Implications for Climate Change Advocacy Intentions," in International Journal of Communication, 2019.

Griffin, Em. A First Look At Communication Theory. New York: Mc Graw Hill, 2003.

Gunawan, Riyan dan Ahmad. "Fungsi Media Massa dalam Perspektif Negara Demokrasi terkait Penyelenggaraan Pemilu," in Seminar Nasional Hukum Universitas Negeri Semarang Jurnal Unnes, Vol. 4, No. 3, Tahun 2018.

Hamada, Basyouni Ibrahim. "Towards a Global Journalism Ethics Model: An Islamic Perspective," in The Journal of International Communication, Vol. 22, 2016.

Jauhari, Iman. "Pelaksanaan dan Penegakan Syariat Islam di Aceh," in Jurnal Hukum Pro Justitia, Vol. 28, April 2010.

Kuncoro, Wahyu. "Eksistensi Ruang Publik di Media," in Jurnal Komunikasi Islam, Vol. 2, No. 2, Desember 2013.

Maulina, Putri. "Pembungkaman Terhadap Perempuan Dalam Teks Pemberitaaan Pelanggaran Syariat Islam di Aceh," in Jurnal Bidayah, Vol. VIII, No. 1, Januari-Juni 2017.

Maulina, Putri. "Penerapan Syariat Islam Dari Sudut Pandang Media dan Perempuan di Aceh," in Jurnal Komunikasi Global, Vol. 8, No. 2, 2019.

McNair. "Journalism and Democracy" in The handbook of Journalisme Studies. New York: Routledge, 2009.

McQuail, Denis. Mass Communication Theory. California: Sage Publication, 1994.

Morissan. Teori Komunikasi Individu dan Massa. Jakarta: Kharisma Putra Utara, 2014.

Moscow, Vincent. The Political Economy of Communication: Rethinking and Renewal. University of Winconsin Press, 1998.

Mulyan, Deddy. Ilmu Komunikasi Sekarang dan Tantangan Masa Depan. Jakarta: Kencana, 2013. 
Nasionalita, Kharisma. "Relevansi Teori Agenda Setting dalam Dunia Tanpa Batas," in Jurnal Ilmiah Komunikasi MAKNA, Vol. 5, No. 2, Agustus 2014-Januari 2015.

Nurlimah, Nila. "Konflik Politik Capres SBY, JK, dan Megawati di Media Massa," in MIMBAR, Vol. XXVII, No. 1, Juni 2011.

Pembayun, Jaduk Gilang. "Konglomerasi Media dan Dampaknya Pada Pilpres 2014," in INTERAKSI, Vol. 4, No. 2, Juli 2015.

Sadikin, Aning Sofyan. "Presiden Wanita dalam Perspektif Media," in Mediator: Jurnal Komunikasi, Vol. 9, No. 2, Desember 2008.

Santosa, Bend Abidin. "Peran Media Massa dalam Mencegah Konflik," in Jurnal ASPIKOM, Vol. 3, No. 2, Januari 2017.

Sauffiyan, Ahmad. "Kempen Politik Trump: Strategi, Taktik Dan Model Perangsaraf Media," in Jurnal Komunikasi, Malaysian Journal of Communication, Jilid 31, No. 1, 2017.

Severin, Werner J., \& James W. Tankard. Communication Theories: Origins, Methods, and Uses in Mass Media. Boston: Addison Wesley Longman, 1997.

Syah, Hakim. "Peran Jurnalisme Islam di Tengah Hegemoni Pers Barat dalam Globalisasi Informasi," Jurnal Komunikasi Islam, Vol. 4, No. 1, Juni 2014.

Syahnan, Mhd. Modernization of Islamic Law of Contract. Jakarta: Badan Litbang \& Diklat Departemen Agama RI, 2009.

Syahnan, Mhd. et al. "Reconsidering Gender Roles in Modern Islam: A Comparison of the Images of Muslim Women Found in the Works of Sayyid Qutb and 'Â'ishah 'Abd Rahmân," in International Journal of Humanities and Social Science Invention, Vol. 6, No. 10, 2017.

Tawaang, Felix. "Newspapers Media Agenda: The Capital Newspapers Content Analysis," in Jurnal Studi Komunikasi dan Media, Vol. 19, No. 1, Januari-Juni 2015.

Veinberg, Sandra. "Most Dominated Problem fo Mass Media Dialogism in National Dailies During The Trial Process of Wikileaks Grounder Julian Assange," in International Journal of Social Science Studies, Vol. 2, No. 2, 2014.

Wiryanto. Teori Komunikasi Massa. Jakarta: Grasindo, 2000.

Wright, Charles R. Sosiologi Komunikasi Massa, tr. Jalaluddin Rakhmat. Bandung: Remaja Karya, 1985.

Saleh, Mohamad Saifudin Mohamad, and Muhammad Syahir Zamri. "Analisis Pelaporan Atlet Wanita Islam Semasa Sukan SEA 2015 dan 2017 in Utusan Online dan Berita Harian Online," in Malaysian Journal of Media Studies, Vol. 21, No. 1, 2019. 